\title{
Pengelompokan Data Persediaan Obat Menggunakan Perbandingan Metode $K$ - Means Dengan Hierarchical Clustering Single Linkage
}

\author{
Rahmatika Diana Firdaus ${ }^{1}$, Tri Ginanjar Laksana ${ }^{2}$, Rima Dias Ramadani ${ }^{3}$ \\ Institut Teknologi Telkom Purwokerto \\ Jl. D.I Panjaitan No. 128 Purwokerto Selatan Jawa Tengah 53147 \\ ${ }^{1} 15102072 @$ ittelkom-pwt.ac.id \\ 2 anjarlaksana@gmail.com \\ ${ }^{3}$ rimadias@ittelkom-pwt.ac.id
}

*Fakultas Teknologi Industri Dan Informatika

Accepted on 09-08-2019

\begin{abstract}
Kesehatan merupakan hak asasi manusia sekaligus investasi bagi keberhasilan pembangunan bangsa Indonesia. Salah satu faktor penting di dunia kesehatan adalah tersedianya obat-obatan untuk nantinya disalurkan ke seluruh wilayah Indonesia melalui badan organisasi kesehatan milik pemerintah secara merata dan berkelanjutan. Fungsi obat yaitu sebagai upaya pencegahan, penyembuhan, maupun peningkatan kesehatan bagi manusia. Obat juga merupakan bahan yang diatur oleh pemerintah dalam hal ini adalah Badan Pengawasan Obat dan Makanan (BPOM). Di era modern seperti saat ini, kita mengenal dengan istilah Data Mining. Dalam perkembangannya, data mining berhubungan erat dengan analisa data, maka dari itu data mining mampu mengolah dan mengelompokan data dalam jumlah yang besar berdasarkan kesamaan dalam sekumpulan data. Algoritma K-Means merupakan metode pengelompokan yang mudah digunakan. Pada proses penentuan titik pusat klaster (centroid) awal merupakan kelemahan bagi K-Means karena sifatnya yang acak. Algoritma Hierarchical Clustering (HCC) Single Linkage pada penentuan titik pusat klaster (centroid) memiliki sifat yang konsisten dan kompleks. Dari 204 data dan variabel yang akan diolah, kedua algoritma tersebut akan mendapatkan klaster optimal data pada kelompok klaster $\mathrm{C} 1$ yaitu obat dengan pemakaian lambat dan klaster $\mathrm{C} 2$ yaitu obat dengan pemakaian cepat dan membandingkan nilai validitasnya. Hasil dari penelitian ini menunjukan bahwa algoritma HCC Single linkage mampu memberikan hasil yang terbaik dengan validitas Sillhoutte Index (SI) sebesar 0.8629 sedangkan algoritma K-Means mendapatkan nilai validitas SI sebesar 0.8414 .
\end{abstract}

Kata Kunci: Algoritma, Data Mining, Hierarchical Clustering, K-Means, Obat, Sillhoutte Index

\section{INTRODUCTION}

Kesehatan merupakan hak asasi manusia dan sekaligus merupakan investasi untuk keberhasilan pembangunan Bangsa Indonesia[1]. Maka dari itu, perlu diadakannya pembangunan kesehatan secara merata 
dan continue. Salah satu unsur penting dalam penjaminan mutu kesehatan adalah dengan adanya ketersediaan obat agar mampu memenuhi kebutuhan kesehatan di masyarakat.

Obat merupakan salah satu komponen yang tak tergantikan dalam pelayanan kesehatan[2]. Fungsi obat yaitu upaya pencegahan, penyembuhan, maupun peningkatan kesehatan bagi manusia. Obat juga merupakan bahan yang diatur oleh pemerintah dalam hal ini adalah Badan Pengawasan Obat dan Makanan (BPOM). Tujuan dari adanya peraturan mengenai obat ini adalah untuk melindungi konsumen dari dampak merugikan karena kualitas dan keamanannya[3]. Berbagai macam obat yang dikonsumsi oleh masyarakat harus sesuai dengan standar BPOM dan menyesuaikan kelas terapi (sesuai keluhan, diagnosa dokter) agar tepat sasaran dan tepat guna.

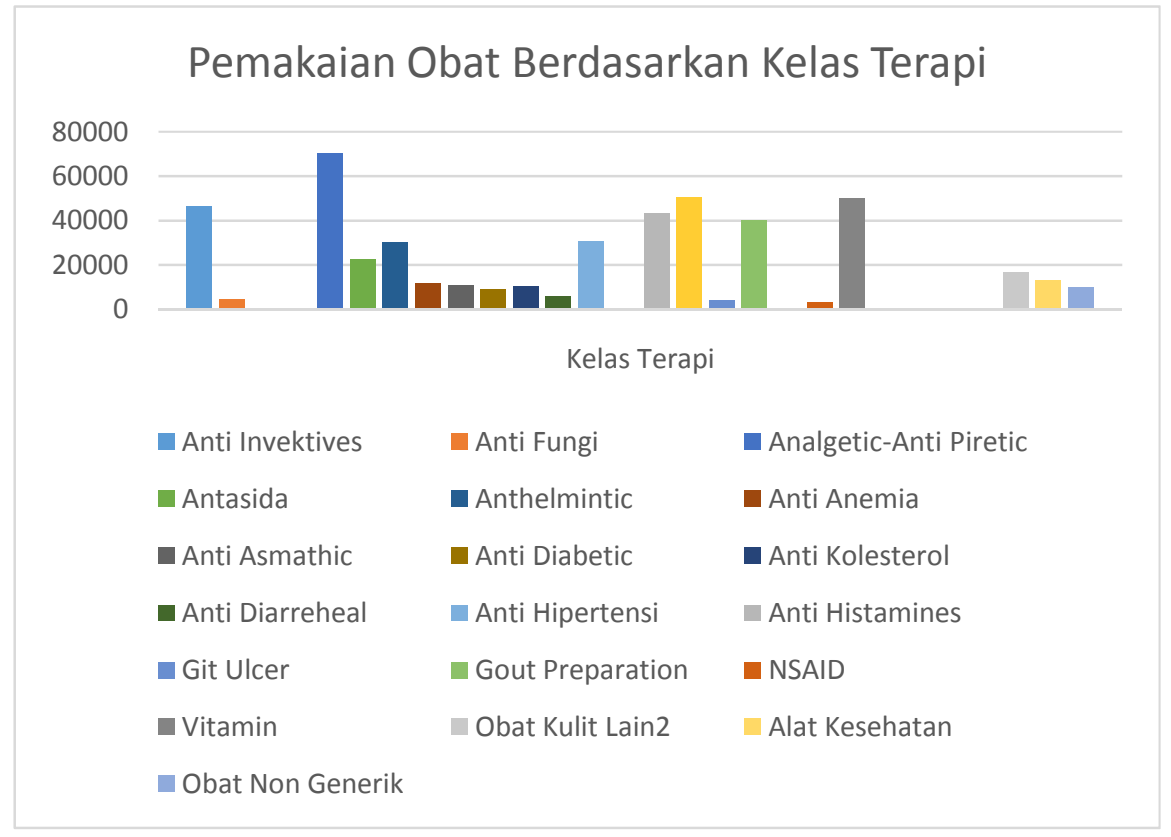

Gambar 1. Jumlah Pemakaian Obat Tahun 2018

Berdasarkan Gambar 1 Merujuk ke Form Laporan Pemakaian Dan Lembar Permintaan Obat (LPLPO) Puskesmas II Ajibarang tahun 2018 tingkat pemakaian obat mencapai angka hampir 80.000 pada obat kelas terapi Analgetic-Antipiretic. Hal ini menandakan bahwa masyarakat tidak bisa lepas dari obat karena termasuk dalam kebutuhan sehari-hari dalam bidang kesehatan. Namun, sistem penanganan pengelompokan obat di Puskesmas II Ajibarang berdasarkan jenis obat yang memiliki varian yang sangat banyak masih dilakukan secara manual dan membutuhkan waktu yang lebih lama. Proses pengelompokan tersebut mengakibatkan terjadinya kesalahan dalam output yang diperoleh sehingga hasil pengelompokan menjadi kurang optimal. Besarnya jumlah pemakaian obat harus diimbangi dengan tersedianya pasokan obat dan tersalurkannya secara merata ke setiap wilayah. Upaya kesehatan dilakukan dengan pendekatan, pemeliharaan, peningkatan kesehatan, pencegahan penyakit, penyembuhan penyakit serta pemulihan kesehatan yang dilakukan secara menyeluruh, terpadu dan berkesinambungan[4]. Peraturan Menteri Kesehatan Nomor 75 Tahun 2014 menyebutkan bahwa Sistem Informasi Kesehatan wajib dilakukan oleh Dinas Kesehatan dan Puskesmas[5]. Berdasarkan form LPLPO Puskesmas II Ajibarang, data didalamnya akan di proses menggunakan algoritma Hirarchical Clustering (HCC) Single Linkage dengan K-Means untuk mendapatkan konvergen (mendekati titik centroid) klaster obat dengan pemakaian lambat (C1) dan obat dengan pemakaian cepat (C2). Sedangkan K-Means bekerja untuk mengelompokkan obat kedalam k kelompok (dimana $\mathrm{k}$ adalah jumlah kelompok yang diinginkan). Algoritma HCC single linkage bekerja untuk menentukan sekumpulan objek dalam hal ini adalah obat menjadi sebuah hierarki sehingga terbentuk kelompok yang memiliki kesamaan menggunakan jarak terdekat[6]. Setelah kovergen klaster dari kedua 
algoritma didapatkan, maka akan dilakukan uji validitas klaster dari tiap-tiap algoritma untuk dibandingkan manakah yang mendapatkan validitas terbaik.

Penelitian yang relevan mengenai pemanfaatan metode $K$-Means pernah dilakukan oleh peneliti Joanna Ardhiyanti M.N, Yupie Kusumawati. Penelitian ini dilakukan untuk menganalisa pemakaian obat sehingga dapat dilakukan perencanaan dan pengendalian persediaan obat dengan mendapatkan jenis obat yang masuk dalam klaster pemakaian cepat dalam waktu 3 tahun terakhir. Hasil dari penelitian ini didapatkan 10 jenis obat pada tahun 2011, 5 jenis obat pada tahun 2012 dan 6 jenis obat pada tahun 2013 serta 2 jenis obat yaitu Klorfeniramin Maleat tb $4 \mathrm{mg}$, Vitamin B kompleks tablet pada gabungan ketiga tahun tersebut. Metode clustering dapat digunakan untuk mengendalikan persediaan obat di Puskesmas Pandanaran[1].

Penelitian lain mengenai analisa perbandingan metode Hierarchical Clustering Single Linkage dan $K$ Means serta gabungan keduanya pernah dilakukan oleh peneliti Tahta Alfina dkk. Latar belakang dari penelitian ini adalah untuk mengelompokan sejumlah data atau objek ke dalam sebuah klaster dimana klaster tersebut akan berisi data semirip mungkin dan berbeda dengan objek dalam klaster lainnya, penggabungan keduanya dengan harapan mendapatkan hasil yang lebih baik. Hasil yang diperoleh adalah gabungan antara metode K-Means dan Hierarchical Clustering Single Linkage memberikan hasil yang terbaik berdasarkan cluster varience yang dibagi menjadi 5 klaster dan mendapatkan nilai $V$ terkecil dan penjumlahan terbesar nilai s pada nilai Sillhoutte[7].

Selanjutnya Peneliti lain Rendy Handoyo dkk dalam membandingkan metode clustering menggunakan Single Linkage dengan K-Means dalam pengelompokan dokumen. Clustering bertujuan untuk mengelompokan dokumen berita berdasarkan tingkat kemiripan dari dokumen tersebut. Hasil yang diperoleh adalah algoritma Single Linkage lebih optimal dalam pengelompokan dokumen dibandingkan $K$-Means dilihat dari nilai Sillhoutte dan Purity dimana algoritma Single Linkage selalu lebih tinggi dari K-Means. Kurang optimalnya algoritma $K$-Means adalah karena proses inisialisasi klaster awal yang dilakukan secara acak. Meskipun dilakukan sebanyak 30 kali iterasi, hasil pengujian-pengujian tersebut belum tentu merepresentasikan suatu klaster yang baik[8].

Dari berbagai kekurangan dan kelebihan yang dimiliki algoritma K-Means dan HCC single Linkage, penulis ingin mengetahui hasil klaster yang didapat dari keduanya dan algoritma mana yang terbaik dilihat dari hasil validitas klaster untuk studi kasus persediaan obat di Puskesmas II Ajibarang. Oleh sebab itu, penelitian ini akan dituangkan ke dalam bentuk tugas akhir dan diberi judul "Pengelompokan Data Persedian Obat Menggunakan Perbandingan Metode K-Means dan Hierarchical Clustering Single Linkage (Studi Kasus di Puskesmas II Ajibarang).

\section{LITERATURE REVIEW}

\section{A. Penelitian Joanna Ardhyanti M.N dan Yupie Kusumawati}

Permasalahan yang diangkat dalam penelitian yang dilakukan oleh Joanna Ardhiyanti M.N, Yupie Kusumawati adalah penelitian belum adanya metode baku untuk menganalisa pemakaian obat yang bermanfaat sebagai perencanaan dan pengendalian persediaan obat. Tujuan dari penelitian ini adalah menganalisa pemakaian obat sehingga dapat dilakukan perencanaan dan pengendalian persediaan obat dengan mendapatkan jenis obat yang masuk dalam klaster pemakaian cepat dalam waktu 3 tahun terakhir. Alur penelitian yang digunakan oleh peneliti mengacu kepada tahapan $K$-Means pada umumya. Penelitian tersebut menghasilkan beberapa jenis obat pada klaster pemakaian lambat dan cepat, namun tujuan dari penelitian ini adalah mendapatkan jenis obat hanya pada pemakaian cepat untuk dilakukan pengendalian persediaan obat pada tahun berikutnya. Kesimpulannya adalah didapatkan 2 jenis obat yang ada pada pemakaian cepat dalam gabungan 3 tahun. Dari penjelasan tersebut, diketahui bahwa metode K-Means clustering merupakan metode yang dapat digunakan untuk pengendalian persediaan obat di Puskesmas Pandanaran Semarang. Data yang digunakan adalah data persediaan obat di Puskesmas Pandanaran tahun 2011-2013 sebanyak 9627 data namun setelahnya dilakukan pre-processing. Atribut yang digunakan diantaranya nama obat, permintaan, pemakaian, stok awal, stok akhir, persediaan, penerimaan. Hasil dari penelitian ini didapatkan 10 jenis obat pada tahun 2011, 5 jenis obat pada tahun 2012 dan 6 jenis obat pada tahun 2013 serta 2 jenis obat yaitu Klorfeniramin 
Maleat tb $4 \mathrm{mg}$, Vitamin B kompleks tablet pada gabungan ketiga tahun tersebut. Metode klastering dapat digunakan untuk mengendalikan persediaan obat di Puskesmas Pandanaran[1].

\section{B. Penelitian Tahta Alfina, dkk}

Penelitian oleh Tahta Alfina, dkk pada tahun 2012 di latar belakangi oleh mengelompokan sejumlah data atau objek ke dalam sebuah klaster dimana klaster tersebut akan berisi data semirip mungkin dan berbeda dengan objek dalam klaster lainnya dan penggabungan keduanya dengan harapan mendapatkan hasil yang lebih baik. Penentuan centroid awal dilakukan oleh algoritma Hierarchical dan setelah didapat maka dilanjutkan dengan pemrosesan data menggunakan algoritma $K$-Means. Pada pengujian performansi algoritma menggunakan Sillhoutte Index menghasilkan algoritma gabungan Hierarchical Clustering dengan metode single linkage dengan K-Means optimal dengan nilai Sillhoutte terbesar yaitu 300 pada pembagian 5 klaster dan gabungan Hierarchical Clustering metode centroid linkage dengan K-Means optimal dengan nilai Sillhoutte terbesar dengan nilai 300 pada pembagian 7 klaster. Hasil yang diperoleh adalah gabungan antara metode K-Means dan Hierarchical klastering single linkage memberikan hasil yang terbaik berdasarkan klaster varience yang dibagi menjadi 5 klaster dan mendapatkan nilai $V$ terkecil dan penjumlahan terbesar nilai $s$ pada nilai Sillhoutte[7].

\section{Penelitian Rendy Handoyo, dkk}

Menurut Penelitian oleh Rendy Handoyo, dkk yang memiliki tujuan untuk mengelompokan dokumen berita berdasarkan tingkat kemiripan dari dokumen tersebut. Hasil yang diperoleh pada semua pengujian menggunakan uji validitas Sillhoutte Index, algoritma HCC Single linkage unggul dibanding K-Means. Pengujian tersebut berupa menguji performansi Clustering dengan dibagi 4 kategori yaitu 25 dokumen, 50 dokumen, 75 dokumen dan 100 dokumen. Pengujian metode HCC Single linkage lebih unggul dibandingkan dengan K-Means dengan mendapatkan nilai Silhouette masing-masing sebesar 0.92, 0.52, 0.33 dan 0.24. Kurang optimalnya algoritma $K$-Means adalah karena proses inisialisasi klaster awal yang dilakukan secara acak. Meskipun dilakukan sebanyak 30 kali iterasi, hasil pengujian-pengujian tersebut belum tentu merepresentasikan suatu klaster yang baik[8].

\section{RESEARCH METHOD}

Studi literatur pada penelitian ini adalah merujuk kepada penelitian sebelumnya yang berkaitan. Studi literatur dilakukan dengan membaca jurnal terkait untuk menentukan metode dan studi kasus yang akan digunakan serta cara penggunaan metode yang ada sebelumnya. Data yang digunakan adalah data form Laporan Pemakaian dan Laporan Permintaan Obat (LPLPO) tahun 2017-2018. Teknik yang digunakan adalah observasi dan wawancara.

Pada penelitan ini terdapat tahapan-tahapan dalam menyelesaikan masalah yang dituangkan dalam flowchart penelitian:

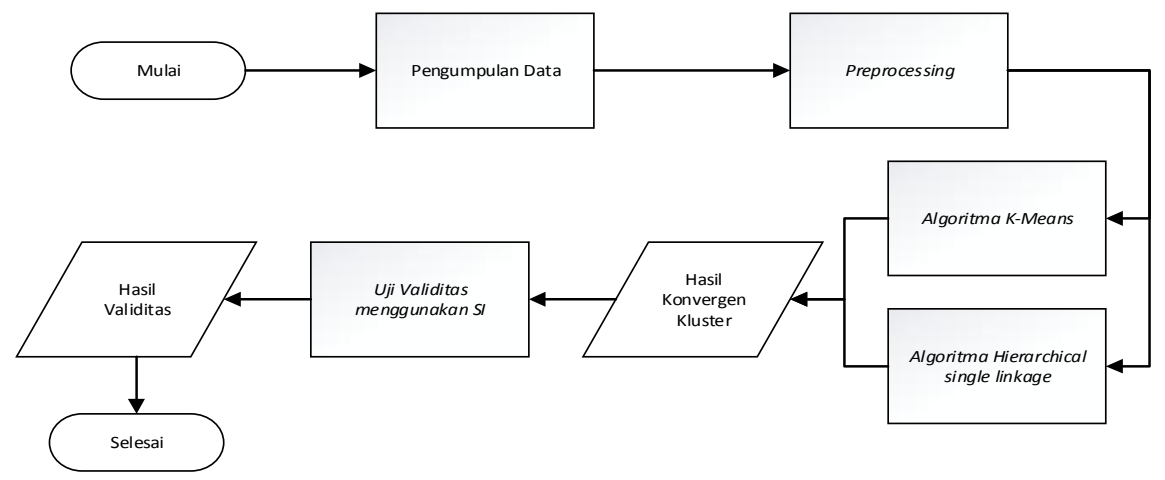

Gambar 3.2. 1 Alur Metode Penelitian 
Berdasarkan flowchart penelitian pada gambar 1 dapat dijelaskan sebagai berikut:

\section{Mulai}

\section{Pengumpulan Data}

Pengumpulan data yaitu menyiapkan data awal form LPLPO di Puskesmas II Ajibarang. Pada penelitian ini, pengumpulan data dilakukan dengan cara mendapatkan data dari Puskesmas II Ajibarang dan menggunakan wawancara. Data yang telah didapatkan berupa form Laporan Pemakaian dan Laporan Permintaan Obat (LPLPO) tahun 2017-2018 yang berformat excel. Terdapat 642 data untuk tahun 2017-2018 tetapi yang digunakan sejumlah 204 karena banyak terdapat data kosong. Data form LPLPO terdapat 9 atribut diantaranya nama obat, satuan, stok awal, penerimaan, persediaan, pemakaian, sisa stok, stok optimal dan permintaan. Atribut yang akan dipakai dalam penelitian ini hanya sebanyak 7 karena apabila stok optimal dan penerimaan dipakai maka akan mempengaruhi hasil klaster.

Tabel 3. 1 Data Obat

\begin{tabular}{|c|c|c|c|c|c|c|c|}
\hline \multirow{2}{*}{$\begin{array}{l}\text { Data } \\
\text { set } \\
\text { ke-i }\end{array}$} & \multicolumn{7}{|c|}{ ATRIBUT } \\
\hline & Nama Obat & Satuan & $\begin{array}{l}\text { Stok } \\
\text { Awal }\end{array}$ & Penerimaan & Persediaan & Pemakaian & Sisa Stok \\
\hline 1 & $\begin{array}{l}\text { Amoksilin } \\
\text { Syr Ker }\end{array}$ & Botol & 1440.00 & 552.00 & 1992.00 & 1349.00 & 643.00 \\
\hline 2 & $\begin{array}{l}\text { Amoksillin } \\
\text { Kap } 500 \\
\text { mg }\end{array}$ & Tablet & 26900.00 & 29000.00 & 55900.00 & 33600.00 & 22300.00 \\
\hline 3 & $\begin{array}{l}\text { Ampisilin } \\
\text { Inj Im/Iv } \\
1000 \mathrm{mg} / \mathrm{ml}\end{array}$ & Vial & 30.00 & 30.00 & 60.00 & 30.00 & 30.00 \\
\hline Ke-n & $\ldots$ & $\ldots$ & $\ldots$ & $\ldots$ & $\ldots$ & $\ldots$ & $\ldots$ \\
\hline
\end{tabular}

Tabel 3.1 menjelaskan bahwa data yang akan digunakan memiliki 7 atribut. Tidak semua atribut yang ada pada tabel 3.1 digunakan. Pada proses selanjutnya, atribut yang digunakan berjumlah 5 diantaranya stok awal, penerimaan, persediaan, pemakaian dan sisa stok.

\section{Preprocessing}

Preprocessing yaitu pemeriksaan data agar terhindar dari redudansi dan data inkonsisten, menghilangkan variabel yang tidak dapat dihitung. Tujuan dilakukannya preprocessing karena metode clustering tidak dapat mengolah data selain angka. Dari tujuh atribut, atribut yang akan diolah sebanyak lima yaitu stok awal, penerimaan, persediaan, Seperti pada tabel 3.2 dibawah ini:

Tabel 3. 2 Data Obat Setelah Preprocessing

\begin{tabular}{|c|c|c|c|c|c|}
\hline \multirow{2}{*}{$\begin{array}{c}\text { Data } \\
\text { set ke-i }\end{array}$} & \multicolumn{5}{|c|}{ ATRIBUT } \\
\cline { 2 - 6 } & $\begin{array}{c}\text { Stok } \\
\text { Awal }\end{array}$ & Penerimaan & Persediaan & Pemakaian & Sisa Stok \\
\hline 1 & 1440.00 & 552.00 & 1992.00 & 1349.00 & 643.00 \\
\hline 2 & 26900.00 & 29000.00 & 55900.00 & 33600.00 & 22300.00 \\
\hline 3 & 30.00 & 30.00 & 60.00 & 30.00 & 30.00 \\
\hline Ke-n & $\ldots$ & $\ldots$ & $\ldots$ & $\ldots$ & $\ldots$ \\
\hline
\end{tabular}

\section{Implementasi algoritma $K$-Means}


Setelah data siap diolah, proses algoritma $K$-Means tertuang dalam flowchart dibawah ini:

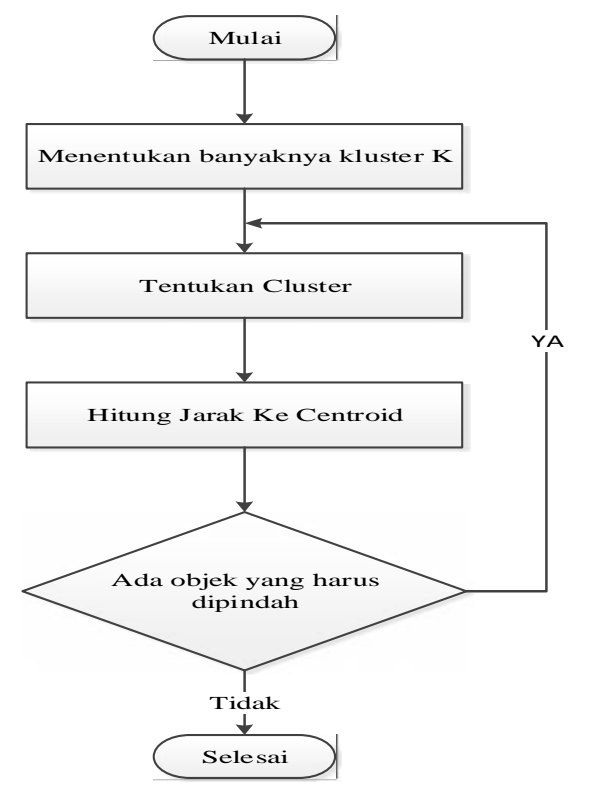

Gambar 3.2.2 Tahapan algoritma K-Means

Berdasarkan dari gambar 3.2.2 Tahapan algoritma $K$-Means dapat dijabarkan sebagai berikut:

a. Mulai

b. Menentukan banyaknya cluster $\mathrm{k}$

Penentuan banyaknya klaster pada penelitian ini, menurut penelitian sebelumnya klaster dibagi menjadi dua yaitu obat dengan pemakaian lambat dan obat dengan pemakaian cepat (C1 dan C2) serta menyesuaikan kebutuhan.

c. Menentukan cluster (titik centroid)

Menurut peneliti Joanna Ardhiyanti M.N dan Yupie Kusumawati, penentuan centroid awal $K$ Means adalah secara acak. Maka dari itu, centroid awal pada penelitian ini diambil 2 data secara acak untuk klaster $\mathrm{C} 1$ dan $\mathrm{C} 2$ berturut-turut atribut masing-masing Antifungi Doen, 123, 24, 147, 55, 92 dan Paracetamol 500 Mg 11800, 54000, 65800, 54200, 11600

d. Menghitung jarak data ke centroid

Tahap selanjutnya adalah menghitung jarak data ke titik centroid dengan menggunakan Euclidean Distance atau jarak terdekat untuk mendapatkan hasil data masuk ke klaster C1 atau klaster C2.

Iterasi pertama jarak data ke centroid $\mathrm{C} 1$

$(\mathrm{d} 1, \mathrm{c} 1)$

$=\sqrt{\left((1440-123)^{\wedge} 2+(552-24)^{\wedge} 2+(1992-147)^{\wedge} 2+(1349-55)^{\wedge} 2+(643-92)^{\wedge} 2\right)}$

$=2719.436523$

(d2,c1)

$=\sqrt{\left((26900-123)^{\wedge} 2+(29000-24)^{\wedge} 2+(55900-147)^{\wedge} 2+(3360055)^{\wedge} 2+(22300-92)^{\wedge} 2\right)}$

$=79268.37707$

$(\mathrm{d} 3, \mathrm{c} 1)$

$=\sqrt{ }\left((30-123)^{\wedge} 2+(30-24)^{\wedge} 2+(60-147)^{\wedge} 2+(30-55)^{\wedge} 2+(30-92)^{\wedge} 2\right)$

$=143.954854$

(d4,c1)

$=\sqrt{ }\left((11200-123)^{\wedge} 2+(6000-24)^{\wedge} 2+(17200-147)^{\wedge} 2+(5200-55)^{\wedge} 2+(12000-92)^{\wedge} 2\right)$ 
$=24849.32198$

$(\mathrm{d} 5, \mathrm{c} 1)$

$=\sqrt{\left((607-123)^{\wedge} 2+(400-24)^{\wedge} 2+(1007-147)^{\wedge} 2+(377-55)^{\wedge} 2+(630-92)^{\wedge} 2\right)}$

$=1228.153085$

(Seterusnya sampai $n$ data).

Iterasi pertama jarak data ke centroid $\mathrm{C} 2$

$(\mathrm{d} 1, \mathrm{c} 2)$

$=\sqrt{ }\left((1440-11800)^{\wedge} 2+(552-54000)^{\wedge} 2+(1992-65800)^{\wedge} 2+(1349-54200)^{\wedge} 2+(643-11600)^{\wedge} 2\right)$

$=84214.13816$

$(\mathrm{d} 2, \mathrm{c} 2)$

$=\sqrt{\left((26900-11800)+(29000-54000)^{\wedge} 2+(55900-65800)^{\wedge} 2+(33600-54200)^{\wedge} 2+(22300-11600)^{\wedge} 2\right)}$

$=29408.24714$

$(\mathrm{d} 3, \mathrm{c} 2)$

$=\sqrt{ }\left((30-11800)^{\wedge} 2+(30-54000)^{\wedge} 2+(60-65800)^{\wedge} 2+(30-54200)^{\wedge} 2+(30-11600)^{\wedge} 2\right)$

$=86766.81583$

$(\mathrm{d} 4, \mathrm{c} 2)$

$=\sqrt{ }\left((11200-11800)^{\wedge} 2+(6000-54000)^{\wedge} 2+(17200-65800)^{\wedge}+(5200-54200)^{\wedge} 2+(12000-11600)^{\wedge} 2\right)$

$=24849.32198$

$(\mathrm{d} 5, \mathrm{c} 2)$

$=\sqrt{\left((607-11800)^{\wedge} 2+(400-54000)^{\wedge} 2+(1007-65800)^{\wedge} 2+(377-54200)^{\wedge} 2+(630-11600)^{\wedge} 2\right)}$

$=1228.153085$

(Seterusnya sampai $\mathrm{n}$ data).

e. Jika masih ada objek atau data yang berpindah maka ulangi iterasi sampai tidak ada lagi yang berpindah.

f. Selesai

\section{Implementasi algoritma HCC Single Linkage}

Data sampel yang akan digunakan untuk perhitungan manual HCC Single Linkage adalah 20\% dari populasi yaitu sebanyak 20 data. Proses algoritma HCC Single Linkage tertuang dalam flowchart dibawah ini:

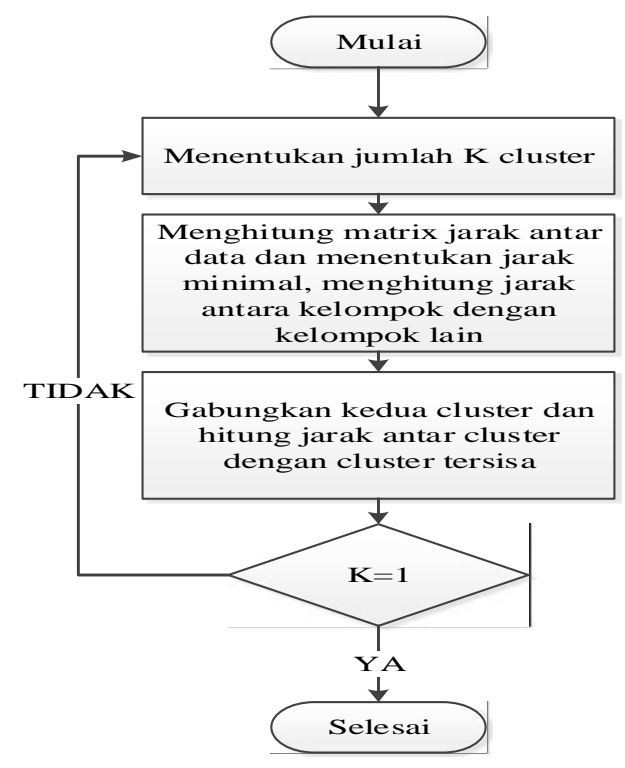

Gambar 3.2. 3 Tahapan HCC Single Linkage 
a. Mulai

b. Menentukan jumlah k cluster

Klaster yang dibentuk pada penelitian ini beradasarkan kebutuhan sebanyak dua yaitu $\mathrm{C} 1$ untuk obat dengan pemakaian lambat dan $\mathrm{C} 2$ untuk obat dengan pemakaian cepat.

c. Menghitung matriks jarak antar data dan menentukan jarak minimal, menghitung jarak antar kelompok dengan kelompok lain

Matriks Jarak antar data

$(1,2)=\sqrt{(1440-26900)^{\wedge} 2+(552-29000)^{\wedge} 2+(1992-55900)^{\wedge} 2+(1349-33600)^{\wedge} 2+(643-22300)^{\wedge} 2}$ $=69719.66$

$(1,3)=\sqrt{(1440-30)^{\wedge} 2+(552-30)^{\wedge} 2+(19992-60)^{\wedge} 2+(1349-30)^{\wedge} 2+(643-30)^{\wedge} 2}$

$=2523.94$

$(1,4)=\sqrt{(1440-11200)^{\wedge} 2+(552-6000)^{\wedge} 2+(1992-17200)^{\wedge} 2+(1349-5200)^{\wedge} 2+(643-12.000)^{\wedge} 2}$

$=22027.24$

$(1,5)=\sqrt{ }(1440-607)+(552-400)^{\wedge} 2+(1992+1007)^{\wedge} 2+(1349-377)^{\wedge} 2+(643-630)^{\wedge} 2$

$=1299.37$

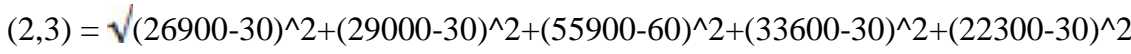

$=79386.78$

$(2,4)=\sqrt{(26900-11200)^{\wedge} 2+(29000-6000)^{\wedge} 2+(55900-17200)-\wedge 2+(33600-5200)^{\wedge} 2+(22300-}$

$12000)^{\wedge} 2$

$=56443.16$

$(2,5)=\sqrt{(26900-607)^{\wedge} 2+(29000-400)^{\wedge} 2+(55900-1007)^{\wedge} 2+(33600-377)^{\wedge} 2+(22300-630)^{\wedge} 2}$

$=78076.12$

$(3,4)=\sqrt{(30-11200)^{\wedge} 2+(30-6000)^{\wedge} 2(60-17200)^{\wedge} 2+(30-5200)^{\wedge} 2+(30-12000)^{\wedge} 2}$

$=24983.98$

$(3,5)=\sqrt{(30-607)^{\wedge} 2+(30-400)^{\wedge} 2+(60-1007)^{\wedge} 2+(30-377)^{\wedge} 2+(30-630)^{\wedge} 2}$

$=1359.06$

$(4,5)=\sqrt{(11200-607)^{\wedge} 2+(6000-400)^{\wedge} 2+(17200-1007)^{\wedge} 2+(5200-377)^{\wedge} 2+(12000-630)^{\wedge} 2}$

$=23628.86$

Seterusnya sampai matriks data $(\mathrm{n}, \mathrm{n})$

d. Menggabungkan kedua klaster dan hitung jarak antar klaster dengan klaster tersisa. Penggabungan klaster diambil dari nilai kelompok paling minimum pada matriks (single linkage) sehingga tersisa hanya satu klaster tunggal $(\mathrm{K}=1)$.

e. Selesai

\section{Hasil klaster optimal kedua algoritma}

Hasil klaster optimal akan didaptkan dari dari algoritma K-Means dan HCC Single Linkage.

\section{Uji validitas}

Uji validitas klaster optimal bertujuan untuk menghitung nilai kesesuaian dari klaster yang telah didapat. Pada penelitian ini menggunakan validitas Sillhoutte Index. Centroid yang digunakan diambil dari baris pertama klaster $\mathrm{C} 1$ dan klaster $\mathrm{C} 2$

\section{Sillhoutte Index K-Means:}

Jarak centroid $\mathrm{C} 1 \mathrm{ke}$ antar data $\mathrm{C} 1$

$(\mathrm{cd} 1, \mathrm{~d} 1)$

$=\sqrt{ }\left((3307-3307)^{\wedge} 2+(6-6)^{\wedge} 2\right)$

$=0$

$(\mathrm{cd} 1, \mathrm{~d} 2)$ 
$=\sqrt{ }\left((3307-7353)^{\wedge} 2+(6-3)^{\wedge} 2\right)$

$=4046.01112$

$(\mathrm{cd} 1, \mathrm{~d} 3)$

$=\sqrt{ }\left((3307-5892)^{\wedge} 2+(6-4)^{\wedge} 2\right)$

$=2585.000774$

Seterusnya sampai data ke- $n$.

Jarak centroid $\mathrm{C} 2$ ke antar data $\mathrm{C} 2$ $(\mathrm{cd} 2, \mathrm{~d} 1)$

$=\sqrt{ }\left((6529-6529)^{\wedge} 2+(9-9)^{\wedge} 2\right)$

$=0$

$(\mathrm{cd} 2, \mathrm{~d} 2)$

$=\sqrt{ }\left((6529-1328)^{\wedge} 2+(9-4)^{\wedge} 2\right)$

$=5201.002403$

$(\mathrm{cd} 2, \mathrm{~d} 3)$

$=\sqrt{ }\left((6529-6798)^{\wedge} 2+(9-4)^{\wedge} 2\right.$

$=269.0464644$

Seterusnya sampai data ke- $\mathrm{n}$.

Jarak centroid $\mathrm{C} 1$ ke antar data $\mathrm{C} 2$

(c1,1)

$=\sqrt{ }\left((3307-6529)^{\wedge} 2+(6-9)^{\wedge} 2\right)$

$=3222.001397$

$(\mathrm{c} 1,2)$

$=\sqrt{ }\left((3307-1328)^{\wedge} 2+(6-4)^{\wedge} 2\right)$

$=1979.001011$

$(\mathrm{c} 1,3)$

$=\sqrt{ }\left((3307-6798)^{\wedge} 2+(6-4)^{\wedge} 2\right)$

$=3491.000573$

Seterusnya sampai data ke- $n$.

Jarak centroid $\mathrm{C} 2$ ke antar data $\mathrm{C} 1$

$(\mathrm{c} 2,1)$

$=\sqrt{ }\left((6529-3307)^{\wedge} 2+(9-6)^{\wedge} 2\right)$

$=3222.001 .397$

$(\mathrm{c} 2,2)$

$=\sqrt{ }\left((6529-7353)^{\wedge} 2+(9-3)^{\wedge} 2\right)$

$=824.0218444$

$(\mathrm{c} 1,1)$

$=\sqrt{ }\left((6529-5892)^{\wedge} 2+(9-4)^{\wedge} 2\right)$

$=637.0196229$

Seterusnya sampai data ke-n

Menjumlahkan, mencari rata-rata dari nilai perhitungan yang diperoleh.

Hasil yang telah diperoleh dari perhitungan sebelumnya, selanjutnya dijumlahkan dan dihitung rataratanya. Perhitungan diambil per kolom yang hasilnya akan diinisialisasi menjadi a1, a2, b1 dan b2. Kemudian Sillhoutte Index akhir menyesuaikan dengan persamaan Sillhoutte Index.

Sillhoutte Index HCC Single Linkage: 
Sama seperti perhitungan Sillhoutte Index pada K-Means, langkah pertama adalah dengan menghitung jarak masing-masing centroid ke data 3,10 atau data $8,18,5, \ldots$ n kemudian menghitung jarak centroid data 3,10 ke data $8,18,5, \ldots$ n dan sebaliknya.

Menghitung jarak centroid $\mathrm{C} 1$ ke data $\mathrm{C} 2$

(cd1,d1)

$=\sqrt{ }\left((143-143)^{\wedge} 2+(9-9)^{\wedge} 2\right)$

$=0$

$(\mathrm{cd} 1, \mathrm{~d} 2)$

$=\sqrt{ }\left((143-187)^{\wedge} 2+(9-8)^{\wedge} 2\right)$

$=44.01136217$

$(\mathrm{cd} 1, \mathrm{~d} 3)$

$=\sqrt{ }\left((143-194)^{\wedge} 2+(9-9)^{\wedge} 2\right)$

$=51$

Seterusnya sampai data ke-n

Menghitung jarak centroid $\mathrm{C} 2$ ke data $\mathrm{C} 1$

$(\mathrm{cd} 2, \mathrm{~d} 1)$

$=\sqrt{ }\left((3859-3859)^{\wedge} 2+(8-8)^{\wedge} 2\right)$

$=0$

$(\mathrm{cd} 2, \mathrm{~d} 2)$

$=\sqrt{ }\left((3859-5644)^{\wedge} 2+(8-1)^{\wedge} 2\right)$

$=1785.013725$

Seterusnya sampai data ke-n.

Menghitung centroid $\mathrm{C} 1$ ke data $\mathrm{C} 2$

(c1,1)

$=\sqrt{ }\left((143-3859)^{\wedge} 2+(9-8)^{\wedge} 2\right)$

$=3716.000135$

$(\mathrm{c} 1,2)$

$=\sqrt{ }\left((143-5644)^{\wedge} 2+(9-1)^{\wedge} 2\right)$

$=5501.005817$

Menghitung centroid $\mathrm{C} 2$ ke data $\mathrm{C} 1$

(c2,1)

$=\sqrt{ }\left((3859-143)^{\wedge} 2+(8-9)^{\wedge} 2\right)$

$=3716.000135$

$(\mathrm{c} 2,2)$

$=\sqrt{\left.(3859-187)^{\wedge} 2+(8-8)^{\wedge} 2\right)}$

$=3672$

(c2,3)

$=\sqrt{\left.(3859-194)^{\wedge} 2+(8-9)^{\wedge} 2\right)}$

$=3665.000136$

Seterusnya sampai data ke-n

Menjumlahkan, mencari rata-rata dari nilai perhitungan yang diperoleh.

Hasil yang telah diperoleh dari perhitungan sebelumnya, selanjutnya dijumlahkan dan dihitung rataratanya. Perhitungan diambil per kolom yang hasilnya akan diinisialisasi menjadi a1, a2, b1 dan b2. Kemudian perhitungan Sillhoutte Index akhir menyesuaikan dengan persamaan Sillhoutte Index. 


\section{Hasil Validitas}

Hasil validitas menunjukan bahwa algoritma $K$-Means mendapatkan nilai validitas sebesar 0.8414 dan algoritma HCC Single Linkage memiliki nilai validitas lebih tinggi dibandingkan $K$-Means yaitu sebesar 0.8629.

Selesai.

\section{RESULT AND DISCUSSION}

\section{Hasil Penelitian}

Pada sub bab hasil penelitian ini, akan dijelaskan tahapan pengumpulan data, preprocessing, hasil perhitungan manual algoritma $K$-Means, hasil perhitungan manual HCC Single Linkage, hasil klaster optimal, dan penentuan algoritma klaster terbaik berdasarkan uji validitas.

\section{Pengumpulan Data}

Tahap pertama dalam penelitian ini adalah melakukan pengumpulan data. Pengambilan data dilakukan di Puskesmas II Ajibarang berupa data Laporan Pemakaian dan Laporan Permintaan Obat (LPLPO) tahun 2017 2018 yang bersifat private. Di dalam form LPLPO terdapat 11 atribut diantaranya nama obat, satuan, stok awal, penerimaan, persediaan, pemakaian, sisa stok, stok optimal, permintaan pemberian, nomor batch dan end serta keterangan.

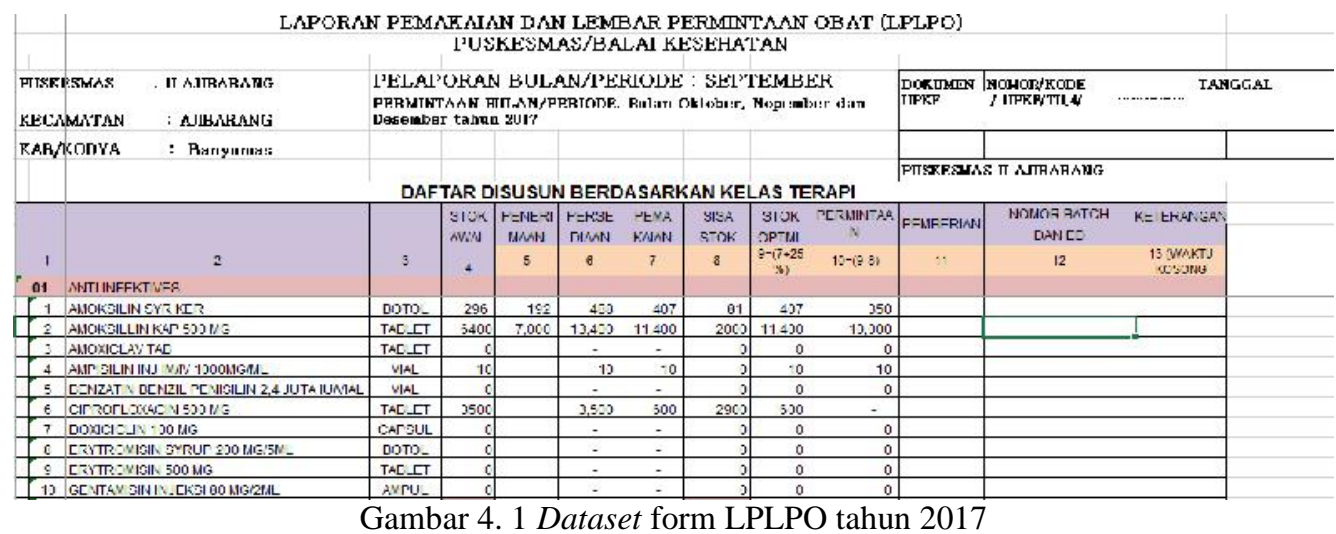

Gambar 4.1 merupakan dataset form LPLPO tahun 2017 yang berisi tentang nama obat, satuan, stok awal, penerimaan, persediaan, pemakaian, sisa stok, stok optimal, permintaan, pemberian, nomor batch dan end serta keterangan. Pada penelitian ini atribut yang digunakan sebanyak 7 yaitu nama obat, ssatuan, stok awal, penerimaan, persediaan, pemakaian dan sisa stok. Penggunaan 7 atribut ini dikarenakan terdapat banyak data yang memiliki missing value yang mempengaruhi atribut stok optimal dan atribut penerimaan. Kemudian pada atribut pemberian, nomor batch dan end serta keterangan adalah kolom kosong. Algoritma clustering hanya dapat memproses data yang berbentuk angka, maka dari itu atribut yang akan diperkecil kembali menjadi 5 berupa stok awal, penerimaan, persediaan, pemakaian, sisa stok dan nama obat hanya sebagai $i d$.

Tabel 4. 1 Dataset form LPLPO tahun 2017-2018

\begin{tabular}{|l|l|c|c|c|c|c|}
\hline No & NAMA OBAT & $\begin{array}{c}\text { STOK } \\
\text { AWAL }\end{array}$ & PENERIMAAN & PERSEDIAAN & PEMAKAIAN & $\begin{array}{c}\text { SISA } \\
\text { STOK }\end{array}$ \\
\hline 1. & $\begin{array}{l}\text { Amoksilin Syr } \\
\text { Ker }\end{array}$ & 1440.00 & 552.00 & 1992.00 & 1349.00 & 643.00 \\
\hline 2. & $\begin{array}{l}\text { Amoksillin } \\
\text { Kap 500 Mg }\end{array}$ & 26900.00 & 29000.00 & 55900.00 & 33600.00 & 22300.00 \\
\hline 3. & $\begin{array}{l}\text { Ampisilin Inj } \\
\text { IM/IV 1000 } \\
\text { Mg/Ml }\end{array}$ & 30.00 & 30.00 & 60.00 & 30.00 & 30.00 \\
\hline
\end{tabular}




\begin{tabular}{|c|c|c|c|c|c|c|}
\hline 4. & $\begin{array}{l}\text { Ciprofloxacin } \\
500 \mathrm{MG}\end{array}$ & 11200.00 & 6000.00 & 17200.00 & 5200.00 & 12000.00 \\
\hline 5. & $\begin{array}{l}\text { Kotrimoksazol } \\
\text { Suspensi } 60 \mathrm{Ml}\end{array}$ & 607.00 & 400.00 & 1007.00 & 377.00 & 630.00 \\
\hline$\ldots$ & $\ldots$ & $\ldots$ & $\ldots$ & $\ldots$ & $\ldots$ & $\ldots$ \\
\hline 642. & Zinkkid Syrup & 0.00 & 528.00 & 528.00 & 308.00 & 220.00 \\
\hline
\end{tabular}

Tabel 4.1 merupakan dataset form LPLPO tahun 2017-2018. Dataset tersebut akan dibersihkan dari data redudansi maupun data inkonsisten.

\section{Preprocessing}

Sebelum melakukan pengujian pada data, data yang sudah tersedia akan diperiksa agar bersih dari redudansi dan data inkonsisten. Pada penelitian ini akan diambil 204 data yang siap olah.

Pada Tabel 4.2 merupakan dataset setelah proses preprocessing dan siap siap olah pengambilan 204 data dikarenakan pembersihan dari banyaknya data inkonsisten dan missing value.

Tabel 4. 2 Dataset setelah proses preprocessing

\begin{tabular}{|l|l|c|c|c|c|c|}
\hline No & NAMA OBAT & $\begin{array}{c}\text { STOK } \\
\text { AWAL }\end{array}$ & PENERIMAAN & PERSEDIAAN & PEMAKAIAN & $\begin{array}{c}\text { SISA } \\
\text { STOK }\end{array}$ \\
\hline 1. & $\begin{array}{l}\text { Amoksilin Syr } \\
\text { Ker }\end{array}$ & 1440.00 & 552.00 & 1992.00 & 1349.00 & 643.00 \\
\hline 2. & $\begin{array}{l}\text { Amoksillin } \\
\text { Kap 500 Mg }\end{array}$ & 26900.00 & 29000.00 & 55900.00 & 33600.00 & 22300.00 \\
\hline 3. & $\begin{array}{l}\text { Ampisilin Inj } \\
\text { IM/IV 1000 } \\
\text { Mg/Ml }\end{array}$ & 30.00 & 30.00 & & & \\
\hline 4. & $\begin{array}{l}\text { Ciprofloxacin } \\
\text { 500 MG }\end{array}$ & 11200.00 & 6000.00 & 17200.00 & 5200.00 & 120000.00 \\
\hline 5. & $\begin{array}{l}\text { Kotrimoksazol } \\
\text { Suspensi 60 Ml }\end{array}$ & 607.00 & 400.00 & 1007.00 & 377.00 & 630.00 \\
\hline$\ldots$ & $\ldots$ & $\ldots$ & $\ldots$ & $\ldots$ & $\ldots$ & \\
\hline 204. & Zinkkid Syrup & 0.00 & 528.00 & 528.00 & 308.00 & 220.00 \\
\hline
\end{tabular}

Hasil perhitungan manual algoritma $\mathrm{K}$-Means

Penentuan centroid awal

Pada penelitian ini, penentuan centroid awal diambil secara acak.

Tabel 4. 3 Centroid Awal

\begin{tabular}{|l|l|l|l|l|l|}
\hline Klaster & \multicolumn{4}{l|}{ Centroid Awal } & \multicolumn{3}{l|}{} \\
\hline C1 & 123.00 & 24.00 & 147.00 & 55.00 & 92.00 \\
\hline C2 & 11800.00 & 5400.00 & 65800.00 & 54200.00 & 11600.00 \\
\hline
\end{tabular}

Pada Tabel 4.3 centroid awal klaster C1 bernilai 123.00 , 24.00 , 147.00 , 55.00 , 92.00 dan untuk klaster C2 bernilai $11800.00,5400.00,65800.00,54200.00,11600.00$.

Perhitungan Jarak data ke centroid

Perhitungan jarak data ke centroid menggunakan Euclidean Distance iterasi pertama menghasilkan nilai dan klaster seperti pada Tabel 4.4

Tabel 4. 4 Hasil jarak data iterasi pertama

\begin{tabular}{|c|c|c|c|c|}
\hline No & C1 & C2 & Terpendek & Klaster \\
\hline 1. & 2719.436523 & 84214.13816 & 2719.436523 & C1 \\
\hline 2. & 79268.37707 & 29408.24714 & 29408.24714 & C2 \\
\hline
\end{tabular}




\begin{tabular}{|c|c|c|c|c|}
\hline 3. & 143.954854 & 86766.81583 & 143.954854 & $\mathrm{C} 1$ \\
\hline 4. & 24849.32198 & 69017.62094 & 24849.32198 & $\mathrm{C} 1$ \\
\hline 5. & 1228.153085 & 85677.41083 & 1228.153085 & $\mathrm{C} 1$ \\
\hline 6. & 17942.88725 & 73198.84562 & 17942.88725 & $\mathrm{C} 1$ \\
\hline 7. & 1304.91494 & 85501.26666 & 1304.91494 & $\mathrm{C} 1$ \\
\hline 8. & 1044.654967 & 85924.81152 & 1044.654967 & $\mathrm{C} 1$ \\
\hline 9. & 3291.535052 & 84472.81693 & 3291.535052 & $\mathrm{C} 1$ \\
\hline 10. & 0 & 86664.46706 & 0 & $\mathrm{C} 1$ \\
\hline$\ldots$ & $\ldots$ & $\ldots$ & $\ldots$ & $\ldots$ \\
\hline 204 & 703.3484201 & 86217.58855 & 703.3484201 & $\mathrm{C} 1$ \\
\hline
\end{tabular}

Tabel 4.4 merupakan hasil perhitungan jarak antar data pada iterasi pertama. Pada iterasi pertama, jumlah anggota klaster C1 sebanyak 186 data dan anggota klaster C2 sebanyak 18 data. Perhitungan $K$-Means terhenti jika anggota klaster sudah tidak ada yang berpindah tata letaknya, untuk memastikan apakah data sudah tidak ada lagi yang berpindah maka perlu dilakukan iterasi kedua. Jika sudah tidak ada lagi data yang berpindah maka iterasi selesai.

Hasil perhitungan manual algoritma HCC Single Linkage

Menghitung jarak antar data

Pada tahap ini, menghitung jarak antar data menggunakan Eucliean Distance.

Tabel 4. 5 Matriks Jarak Antar Data

\begin{tabular}{|l|l|l|l|l|}
\hline Data & 1 & 2 & 3 & $\ldots \mathrm{n}$ \\
\hline 1 & 0.00 & 76633.71 & 2847.58 & $\ldots$ \\
\hline 2 & 76633.71 & 0.00 & 79386.78 & $\ldots$ \\
\hline 3 & 2847.58 & 79386.78 & 0.00 & $\ldots$ \\
\hline 4 & 22361.42 & 56443.16 & 24983.98 & $\ldots$ \\
\hline 5 & 1622.40 & 78076.12 & 1359.06 & $\ldots$ \\
\hline 6 & 15445.36 & 62297.27 & 18074.93 & $\ldots$ \\
\hline 7 & 1601.75 & 78019.68 & 1402.57 & $\ldots$ \\
\hline 8 & 1880.62 & 78318.98 & 1177.65 & $\ldots$ \\
\hline 9 & 1761.20 & 76382.85 & 3424.21 & $\ldots$ \\
\hline 10 & 2719.44 & 79268.38 & 143.95 & $\ldots$ \\
\hline$\ldots \mathrm{n}$ & $\ldots$ & $\ldots$ & $\ldots$ & $\ldots$ \\
\hline
\end{tabular}

Pada Tabel 4.5 merupakan matriks jarak antar data yang dihitung menggunakan rumus Euclidean Distance. Pada tahap ini akan diambil nilai terkecil dari perhitungan single linkage atau jarak minimum. Dari tabel diatas dapat diambil nilai pada kelompok 3 dan 10 sebagai jarak minimum sebesar 143.95 dan kelompok tersebut akan digabungkan menjadi satu kelompok yaitu $(3,10)$. Selanjutnya akan dihitung kembali kelompok yang sudah didapat $(3,10)$ dengan kelompok lain yang tersisa.

Tabel 4. 6 Hasil perhitungan data

\begin{tabular}{|c|c|}
\hline Data & Nilai \\
\hline$(3,10)$ & 143.95 \\
\hline$(10,3)$ & 143.95 \\
\hline$(8,18)$ & 187.85 \\
\hline$(5 ; 8,18)$ & 194.99 \\
\hline$(13,16)$ & 218.47 \\
\hline$(5,8,18 ; 3,16)$ & 253.84 \\
\hline$(5,8,18,13,16 ; 17)$ & 297.26 \\
\hline$(5,8,18,13,16,17 ; 11)$ & 308.67 \\
\hline
\end{tabular}




\begin{tabular}{|c|c|}
\hline$(3,10 ; 5,8,18,13,16,17,11)$ & 4219.91 \\
\hline$(3,10,5,8,18,13,16,17,11 ; 7)$ & 588.50 \\
\hline$(3,10,5,8,18,13,16,17,11,7 ; 15)$ & 629.53 \\
\hline$(1 ; 3,10,5,8,18,13,16,17,11,7,15)$ & 1601.75 \\
\hline$(1,3,10,5,8,18,13,16,17,11,7,15 ; 9)$ & 1761.20 \\
\hline$(1,3,10,5,8,18,13,16,17,11,7,15,9 ; 14)$ & 1967.23 \\
\hline$(1,3,10,5,8,18,13,16,17,11,7,15,9,14 ; 20)$ & 2605.99 \\
\hline$(6,12)$ & 4885.53 \\
\hline$(4 ; 6,12)$ & 7005.71 \\
\hline$(1,3,10,5,8,18,13,16,17,11,7,15,9,14,20 ; 4,6,12)$ & 21613.65 \\
\hline$(2 ; 19)$ & 38598.83 \\
\hline$(2,19)$ & 56443.16 \\
\hline
\end{tabular}

Tabel 4.6 merupakan hasil perhitungan data menggunakan Single Linkage. Perhitungan berhenti setalah mendapatkan nilai kelompok klaster tunggal dan pada tabel diatas dapat diketahui kelompok luster terakhir adalah kelompok $(2,19)$. Dari 20 data yang menjadi sampel sebanyak 18 data masuk ke dalam klaster $\mathrm{C} 1 \mathrm{dan}$ 2 data masuk ke klaster $\mathrm{C} 2$.

\section{Hasil klaster optimal}

Klaster optimal dari proses sebelumnya didapatkan hasil untuk algoritma $K$-Means klaster $\mathrm{C} 1$ sebanyak 180 data, klaster C2 sebanyak 24 data. Algoritma HCC Single Linkage klaster optimal C1 sebanyak 203 data dan klaster 2 sebanyak 1 data.

\section{Hasil Validitas terbaik}

Hasil uji validitas, algoritma HCC Single Linkage memperoleh hasil yang lebih optimal dibandingkan denga algoritma K-Means dengan nilai sebesar 0.8629 banding 0.8414 berdasarkan perhitungan Sillhoutte Index.

\section{Hasil Pengujian}

Pada penelitian ini, penulis menguji nilai klaster optimal dan nilai validitas menggunakan 4 kategori data yaitu 100 data, 150 data, 200 data dan 204 data untuk menguji performansi clustering dengan data set tersebut menghasilkan

Tabel 4. 7 Hasil pengujian $K$-Means

\begin{tabular}{|c|c|c|c|}
\hline \multirow{2}{*}{ Data } & \multicolumn{2}{|c|}{ Klaster } & \multirow{2}{*}{ Validitas } \\
\cline { 2 - 3 } & C1 & C2 & \\
\hline 100 & 11 & 89 & 0.7883 \\
\hline 150 & 132 & 18 & 0.8343 \\
\hline 200 & 177 & 23 & 0.8393 \\
\hline 204 & 180 & 24 & 0.8414 \\
\hline
\end{tabular}

Tabel 4.7 merupakan hasil pengujian menggunakan 100 data, 150 data, 200 data dan 204 data. Pada tabel tersebut menunjukan bahwa jumlah data pada algoritma $K$-Means mempengaruhi klaster optimal dari klaster $\mathrm{C} 1$ dan klaster C2. Jumlah data juga mempengaruhi dari nilai validitas yang didapat, semakin banyak data yang diolah hasil validitasnya semakin baik.

Tabel 4. 8 Hasil Pengujian HCC Single Linkage

\begin{tabular}{|c|c|c|c|}
\hline \multirow{2}{*}{ Data } & \multicolumn{2}{|c|}{ Klaster } & \multirow{2}{*}{ Validitas } \\
\cline { 2 - 3 } & C1 & C2 & \\
\hline 100 & 99 & 1 & 0.7838 \\
\hline 150 & 149 & 1 & 0.8573 \\
\hline 200 & 199 & 1 & 0.8611 \\
\hline 204 & 203 & 1 & 0.8629 \\
\hline
\end{tabular}


Tabel 4.8 merupakan hasil pengujian menggunakan 100 data, 150 data, 200 data dan 204 data. Pada tabel tersebut menunjukan bahwa jumlah data tidak terlalu mempengaruhi karena metodenya yang menggunakan single linkage atau menghitung sampai klaster tunggal $(\mathrm{K}=1)$. Dapat dilihat dari klaster $\mathrm{C} 2$ dari 4 pengujian adalah jumlah klaster konvergennya yang sama yaitu 1 (tunggal). Semakin banyak data yang diolah hasil validitasnya semakin optimal.

\section{B. Analisis}

Pada proses Algoritma K-Means, penentuan centroid awal dilakukan secara acak. Maka dari itu setiap data memiliki probabilitas (kemungkinan) yang sama untuk dipilih sebagai centroid awal. Kurang optimalnya algoritma $K$-Means terletak pada penentuan centroid awal tersebut. Jika centroid awalnya berubah maka akan mempengaruhi nilai secara keseluruhan sampai pada hasil klaster optimal dan validasi yang akan ikut berubah. Pada hasil pengujian menggunakan 4 kategori data, terlihat jumlah data mempengaruhi hasil klaster optimal dan nilai validitasnya. Pada hasil pengujian dengan 204 data, klaster optimal mendapatkan 180 data berada pada klaster C1 (obat dengan pemakaian lambat) dan 24 data berada pada klaster C2 (obat dengan pemakaian cepat) menandakan bahwa data-data tersebut mendekati atau menuju ke titik pusat klaster (centroid). Hasil klaster optimal direpresentasikan dengan plot yang berupa titik-titik menyesuaikan dari tiap klaster yang dapat dengan mudah dibaca dan dipahami.

Pada proses algoritma HCC Single Linkage, penentuan centroid awal dilakukan secara konsisten dengan menghitung jarak antar data kemudian diambil nilai terkecil dari nilai jarak antar data tersebut. Semua kelompok yang dibentuk berdasarkan entities individu dan menggabungkan jarak dari tiap kelompok dengan nilai paling kecil atau similarities (kemiripan) data yang paling besar. Penggabungan dua kelompok tersebut merupakan hasil akhir dari proses algoritma ini karena dua kelompok yang telah digabung tidak bisa dikembalikan seperti semula. Algoritma HCC Single Linkage merupakan algoritma yang kompleks, maka dari itu pengerjaannya membutuhkan waktu sedikit lebih lama dibandingkan dengan $K$-Means yang sedehana dan mudah. Pada hasil pengujian menggunakan 4 kategori data, terlihat jumlah data tidak begitu mempengaruhi hasil klaster optimal tetapi semakin banyak data yang diolah, hasil dari nilai validitasnya akan semakin optimal. Pada hasil klaster optimal C1 mendapatkan 203 data berada pada klaster C1 (obat dengan pemakaian lambat) dan 1 data berada pada klaster C2 (obat dengan pemakaian cepat) menandakan bahwa data-data tersebut sudah berada pada tingkat kemiripan yang paling besar. Berbeda dengan algoritma K-Means, hasil dari klaster optimal di representasikan dengan dendogram berupa bagan kelompok klaster yang tujuannya sama seperti plot pada K-Means untuk lebih mudah dibaca dari proses algoritma HCC Single Linkage.

Dari hasil klaster optimal, setelahnya dihitung berapa nilai validitas dari kedua algoritma tersebut dan selisih nilai validitas kedua algoritma tidak terlalu jauh hanya sebesar 0.0215 . Nilai validitas tertinggi didapatkan oleh algoritma HCC Single Linkage. Hal ini disebabkan karena pembangkitan titik pusat klaster (centroid) secara acak sehingga centroid yang diperoleh belum tentu centroid yang didominasi oleh data yang lebih banyak kemiripannya. Sedangkan pada HCC Single Linkage, titik pusat klaster (centroid) dilakukan dengan konsisten, sehingga centroid didominasi dengan data yang lebih banyak kemiripannya.

Hasil dari uji validitas algoritma K-Means dan HCC Single Linkage memiliki tingkat validitas yang tinggi karena mendapatkan nilai masing-masing sebesar 0.8414 dan 0.8629 . Nilai ukuran dari vvaliditas kedua algoritma tersebut adalh Strong Structure karena memiliki nilai Sillhoutte Index lebih dari 0.7.

Penelitian ini relevan dengan peneliti Joanna Ardhiyanti M.N dan Yupie Kusumawati bahwa dari proses algoritma $K$-Means hasil yang didapat adalah obat dengan pemakaian lambat dan obat dengan pemakaian cepat. Sejalan dengan penelitian milik Undang Syaripudin, dkk bahwa algoritma Hierarchical Clustering lebih kompleks dan lama dalam pengerjaannya dibanding algoritma K-Means yang sederhana dan cepat. Peneliti Rendy Handoyo, dkk menyebutkan bahwa kurang optimalnya K-Means disebabkan karena proses inisialisasi klaster yang dilakukan secara acak peda pembangkitan klaster awal.Oleh karena itu, sulit untuk mendapatkan klaster awal yang unik. Meskipun dilakukan iterasi sebanyak beberapa kali, namun hasil iterasi tersebut belum tentu merepresentasikan suatu klaster yang baik dianggap searah dengan penelitian ini.

\section{CONCLUSSION}

Merujuk ke rumusan masalah dan tujuan penelitian, kesimpulan yang dapat diambil dari penelitian ini adalah sebagai berikut: 
1. Algoritma K-Means dan HCC Single Linkage mampu mendapatkan klaster optimal sesuai dengan data kemiripan. Klaster optimal yang didapat dari kedua algoritma yaitu algoritma K-Means 180 data berada pada $\mathrm{C} 1$ atau obat dengan pemakaian lambat dan 24 data berada pada $\mathrm{C} 2$ atau obat dengan pemakaian cepat. Algoritma HCC Single Linkage dengan hasil 203 data berada pada C1 atau obat dengan pemakaian lambat dan 1 data berada pada $\mathrm{C} 2$ atau obat dengan pemakaian cepat.

2. Nilai validitas algoritma $k$-Means dan HCC Single Linkage tergolong tinggi (strong structure) dibuktikan dengan pengujian validitas Sillhoutte Index masing-masing mendapatkan nilai validitas SI sebesar 0.8014 dan 0.8629. Oleh karena itu, nilai validitas terbaik berdasarkan pengujian SI diantara keduanya diperoleh algoritma HCC Single Linkage.

\section{REFERENCES}

[1] J. Ardhyanti, M. Nugraha, Y. Kusumawati, S. Informasi, F. I. Komputer, and U. D. Nuswantoro, "Data Mining Dengan Metode Clustering Untuk Pengolahan Informasi Persediaan Obat Pada Puskesmas Pandanaran Semarang,” UDiNus Repos., vol. 1, no. 1, p. $1,2014$.

[2] BPOM, "Materi Edukasi tentang Peduli Obat dan Pangan Aman," GNPOPA (Gerakan Nas. Peduli Obat Dan Pangan Aman), vol. 1, no. 1 , p. $5,2015$.

[3] P. F. Sujati Woro Indijah, Farmakologi. 2016.

[4] Supriani, "Evaluasi Siklus Pengelolaan Obat Tentang Distribusi Obat Askes di IFRS RSUD Ajibarang Banyumas," 2-Trik, vol. 8, no. 1, p. 1, 2018.

[5] M. K. Sadiyanto, SKM., "Dinas Kesehatan Kabupaten Banyumas,” vol. 1, no. 1, pp. 1-180, 2015

[6] U. Syaripudin, I. Badruzaman, E. Yani, and M. Ramdhani, "Studi Komparatif Penerapan Metode Hierarchical, K-Means Dan Self Organizing Maps (SOM) Clustering Pada Basis Data," vol. VII, no. 1, pp. 132-149, 2013.

[7] T. Alfina, B. Santosa, and R. Barakbah, "Analisa Perbandingan Metode Hierarchical Clustering , K-means dan Gabungan Keduanya dalam Cluster Data ( Studi kasus: Problem Kerja Praktek Jurusan Teknik Industri ITS ),” J. Tek. ITS, vol. 1, no. Data Mining, pp. 1-5, 2012.

[8] R. Handoyo, S. M. Nasution, P. Studi, S. Komputer, S. Linkage, S. Coefficient, R. Handoyo, and S. M. Nasution, "Perbandingan Metode Clustering Menggunakan Metode Single Linkage Dan K-Means Pada Pengelompokan Dokumen," JSM STMIK Mikroskil, vol. 15 , no. 2 , pp. $73-82,2014$.

[9] A. S. A. Ali Ridho Barakbah, Tita Karlita, Logika dan algoritma. 2013.

[10] A. P. Windarto, D. Hartama, and S. Solikhun, "Komparasi Kinerja Algoritma Fuzzy C-Means Dan K-Means Dalam Pengelompokan Data Siswa Berdasarkan Prestasi Nilai Akademik Siswa ( Studi Kasus: SMP Negeri 2 Pematangsiantar )," JURASIK (Jurnal Ris. Sist. Inf. Tek. Inform., vol. 1, no. 1, pp. 1-9, 2016.

[11] Bertalya, "Konsep Data Mining," Data Min. Knowl. Discov. Databases, 2009.

[12] J. Han, M. Kamber, and J. Pei, Data Mining: Concepts and Techniques. 2012.

[13] Amirulloh, Populasi dan sampel. 2015.

[14] R. Nasution, “Teknik Sampling," Usu Digit. Libr., vol. 1, no. 2, pp. 1-7, 2003.

[15] M. Tania, "Hubungan Pengetahuan Remaja Dengan Konsumsi Minuman Ringan di SMKN Baleendah Bandung," J. Ilmu Keperawatan, vol. IV, no. 1, 2016.

[16] W. Budiharto, Pengantar Praktis Pemrograman R untuk Ilmu Komputer. 2013.

[17] A. Segonds, Introduction to ggplot2. 2015.

[18] K. Ram, "Data Visualization Using R \& ggplot2 Some housekeeping." p. 4, 2013.

[19] N. Ghazzali, "NbClust: An R Package for Determining the," J. Stat. Softw., vol. 61, no. 6, 2014

[20] M. S. Wafa, "Evaluasi Kinerja Akademik Mahasiswa Menggunakan Algoritma K-Means Clustering," Univ. Islam Negeri Maulana Malik Ibrahim Malang, vol. 1, pp. 1-117, 2013.

[21] S. Agustina, D. Yhudo, H. Santoso, N. Marnasusanto, A. Tirtana, and F. Khusnu, "Clustering Kualitas Beras Berdasarkan Ciri Fisik Menggunakan Metode K-Means," Clust. K-Means, vol. 1, no. 1, pp. 1-7, 2012.

[22] Asroni and R. Adrian, "Penerapan Metode K-Means untuk Clustering Mahasiswa Berdasarkan Nilai Akademik dengan Weka Interface Studi Kasus pada Jurusan Teknik Informatika UMM Magelang,” J. Ilm. Semesta Tek., vol. 18, no. 1, pp. 76-82, 2015.

[23] I. Wahyuni, Y. A. Auliya, A. Rahmi, and W. F. Mahmudy, "Clustering Nasabah Bank Berdasarkan Tingkat Likuiditas Menggunakan Hybrid Particle Swarm Optimization dengan K-Means,” J. Ilm. Teknol. dan Inf. ASIA, vol. 10, no. 2, pp. 24-33, 2016.

[24] S. Mashfuufah and D. Istiawan, "Penerapan Partition Entropy Index , Partition Coefficient Index dan Xie BeniIndex untuk Penentuan Jumlah Klaster Optimal pada Algoritma Fuzzy C-Means dalam Pemetaan Tingkat Kesejahteraan Penduduk Jawa Tengah," URECOL, vol. 1, no. 1, pp. 51-60, 2018.

[25] A. Ramadhan and Z. Efendi, "Perbandingan K-Means dan Fuzzy C-Means untuk Pengelompokan Data User Knowledge Modeling," SNTIKI, vol. 1, no. 2, pp. 18-19, 2017.

[26] G. P. Trayasiwi, "Penerapan Metode Klastering Dengan Algoritma K-Means Untuk Prediksi Kelulusan Mahasiswa Pasa Program Studi Teknik Informatika Strata Satu,” UDiNus Repos., vol. 1, no. 1, pp. 1-11, 2017.

[27] Kemenkes RI, "Keputusan Menteri Kesehatan Republik Indonesia Nomor 189/MENKES/SK/III/2006 Tentang Kebijakan Obat Nasional," Kementrian Kesehat., pp. 4-8, 2010. 